\title{
The elevation of Creatine kinase in acute pancreatitis: a case report
}

Mehdi Sheibani ${ }^{1}$, Bahareh Hajibaratali ${ }^{1}$, and Houra Yeganegi ${ }^{1}$

${ }^{1}$ Shahid Beheshti University of Medical Sciences

October 21, 2021

\begin{abstract}
Creatine Kinase (CK/CK-MB) testing is an essential lab test approaching patients with chest or epigastric pain. we report a 38-year-old man with acute pancreatitis and elevated CK/CK-MB level without myocardial involvement. Acute pancreatitis may be considered as a false positive cause of CK/CK-MB test in patients presenting with chest pain.
\end{abstract}

\section{Hosted file}

main document.docx available at https://authorea.com/users/442216/articles/542535-theelevation-of-creatine-kinase-in-acute-pancreatitis-a-case-report

\section{Hosted file}

figure 1.docx available at https://authorea.com/users/442216/articles/542535-the-elevationof-creatine-kinase-in-acute-pancreatitis-a-case-report 